NBER WORKING PAPER SERIES

BANK CEO INCENTIVES AND THE CREDIT CRISIS

\author{
Rüdiger Fahlenbrach \\ René M. Stulz \\ Working Paper 15212 \\ http://www.nber.org/papers/w15212 \\ NATIONAL BUREAU OF ECONOMIC RESEARCH \\ 1050 Massachusetts Avenue \\ Cambridge, MA 02138 \\ August 2009
}

Fahlenbrach is Swiss Finance Institute Assistant Professor at Ecole Polytechnique Fédérale de Lausanne. Stulz is the Everett D. Reese Chair of Banking and Monetary Economics, Fisher College of Business, Ohio State University, and affiliated with NBER and ECGI. Fahlenbrach acknowledges financial support from the Dice Center for Research in Financial Economics. Address correspondence to René M. Stulz, Fisher College of Business, The Ohio State University, 806 Fisher Hall, Columbus, OH 43210, stulz@cob.osu.edu. The views expressed herein are those of the author(s) and do not necessarily reflect the views of the National Bureau of Economic Research.

NBER working papers are circulated for discussion and comment purposes. They have not been peerreviewed or been subject to the review by the NBER Board of Directors that accompanies official NBER publications.

(C) 2009 by Rüdiger Fahlenbrach and René M. Stulz. All rights reserved. Short sections of text, not to exceed two paragraphs, may be quoted without explicit permission provided that full credit, including (C) notice, is given to the source. 
Bank CEO Incentives and the Credit Crisis

Rüdiger Fahlenbrach and René M. Stulz

NBER Working Paper No. 15212

July 2009

JEL No. G01,G21,G32

\begin{abstract}
We investigate whether bank performance during the credit crisis of 2008 is related to CEO incentives and share ownership before the crisis and whether CEOs reduced their equity stakes in their banks in anticipation of the crisis. There is no evidence that banks with CEOs whose incentives were better aligned with the interests of their shareholders performed better during the crisis and some evidence that these banks actually performed worse both in terms of stock returns and in terms of accounting return on equity. Further, option compensation did not have an adverse impact on bank performance during the crisis. Bank CEOs did not reduce their holdings of shares in anticipation of the crisis or during the crisis; further, there is no evidence that they hedged their equity exposure. Consequently, they suffered extremely large wealth losses as a result of the crisis.
\end{abstract}

Rüdiger Fahlenbrach

Ecole Polytechnique Fédérale de Lausanne (EPFL)

Odyssea 2.01 B, Station 5

1015 Lausanne

Switzerland

Ruediger.fahlenbrach@epfl.ch

René M. Stulz

The Ohio State University

Fisher College of Business

806A Fisher Hall

2100 Neil Avenue

Columbus, $\mathrm{OH}$ 43210-1144

and NBER

stulz_1@cob.osu.edu 
In the search of explanations for the dramatic collapse of the stock market capitalization of much of the banking industry in the U.S. during the credit crisis, one prominent argument is that executives at banks had poor incentives. For instance, Blinder argues that these poor incentives are "one of [the] most fundamental causes" of the credit crisis. ${ }^{1}$ The argument seems to be that executives' compensation was not properly related to long-term performance, leading the Obama administration to discuss ways to change compensation practices "to more closely align pay with long-term performance",2 and to give more voice to shareholders through the adoption of "say on pay" for firms that received public funds through the Troubled Asset Relief Program. ${ }^{3}$

We investigate in this paper how closely the interests of the CEOs of banks were aligned with those of their shareholders before the start of the crisis, whether the alignment of interests between CEOs and shareholders can explain the performance of banks in the cross-section during the credit crisis, and how CEOs fared during the crisis. Traditionally, corporate governance experts and economists since Adam Smith have considered that management's interests are better aligned with those of shareholders when managers' compensation increases when shareholders gain and falls when shareholders lose. Our results show that there is no evidence that banks with a better alignment of CEOs' interests with those of their shareholders had higher stock returns during the crisis and some evidence that banks led by CEOs whose interests were better aligned with those of their shareholders had worse stock returns and a worse return on equity. Though options have been blamed for leading to excessive risk-taking, there is no evidence in our sample that greater sensitivity of CEO pay to stock volatility led to worse stock returns during the credit crisis. A plausible explanation for these findings is that CEOs focused on the interests of their shareholders in the build-up to the crisis and took actions that they believed the market would welcome. Ex post,

\footnotetext{
1 "Crazy compensation and the crisis," by Alan Blinder, The Wall Street Journal, May 28, 2009.

2 "U.S. eyes bank pay overhaul: Administration in early talks on ways to curb compensation across finance," The Wall Street Journal, May 13, 2009.

3 "U.S. targets excessive pay for top executives," by David Cho, Zachary A. Goldfarb and Tomoeh Murakami Tse, The Washington Post, June 11, 2009; "US SEC proposes say on pay for TARP companies," by James Pehtokoukis, Reuters, July 1, 2009.
} 
these actions were costly to their banks and to themselves when the results turned out to be poor. These poor results were not expected by the CEOs to the extent that they did not reduce or hedge their holdings of shares in anticipation of poor outcomes.

There are many versions of the poor incentives explanation of the crisis. One version is that CEOs were focused on the short run rather than the long run. Another version is that option compensation gave incentives to CEOs to take more risks than would have been optimal for shareholders. A third version is that the high leverage of financial institutions implies that CEOs can increase the value of their shares by increasing the volatility of the assets since the shares are effectively options on the value of the assets. ${ }^{4}$ To the extent that the market for a bank's stock is efficient, changes in a bank's long-term performance will be properly reflected in the stock price, so that greater sensitivity of a CEO's wealth to his bank's stock price will make it advantageous for the CEO to improve his bank's long-term performance when it makes economic sense to do so. Focusing on the short run rather than the long run would be costly for CEOs since their stock price would be lower than if they took actions to maximize shareholder wealth. The incentive effects of options would be diluted in the CEO's portfolio if he has large holdings of shares. Keeping the CEO's holdings of his firm's stock constant, greater sensitivity of his wealth to increases in the volatility of his firm's stock return brought about by greater stock option holdings would increase the CEO's incentives to take risks as long as these options are not too much in the money. Whether greater sensitivity of CEO wealth to volatility makes the CEO's interests better aligned with the interests of shareholders would seem to depend on many considerations. For example, if the CEO's holdings of stock make him more conservative, greater sensitivity of his wealth to volatility would help in aligning the CEO's incentives with those of shareholders.

CEOs with greater incentive alignment would therefore be expected to take different risks from those with weaker incentive alignment. To the extent that the bank exposures that performed poorly during the crisis were viewed as risky by CEOs in 2006, we would expect that bank CEOs with

\footnotetext{
${ }^{4}$ See Bebchuck and Spamann (2009).
} 
greater incentive alignment would have chosen to take fewer such exposures than CEOs with poor incentive alignment: CEOs with low holdings of shares would have had much less to lose in the event of bad outcomes as a result of these exposures. Further, CEOs with more options in their portfolio relative to shares would have been more willing to take risky exposures.

We find that bank CEOs had substantial wealth invested in their banks. On average, the value of stock and options in the CEO's portfolio was more than ten times the value of the CEO's compensation in 2006. Consequently, changes in his bank's stock price could easily wipe out all a CEO's annual compensation. On average, CEOs owned $1.6 \%$ of the outstanding shares of their bank. Taking into account vested, but unexercised options, this fraction increases to $2.4 \%$. The large holdings of vested unexercised options are striking. They are not consistent with the view that somehow the typical CEO knew that there was a substantial risk of a crash in the stock price of his bank.

A bank's stock return performance in 2007-2008 is negatively related to the dollar value of a CEO's holdings of shares in 2006. This effect is substantial. An increase of one standard deviation in dollar ownership is associated with lower returns of $10.2 \%$. Similarly, a bank's return on equity in 2008 is negatively related to its CEO's holdings of shares in 2006 - a one standard deviation increase in dollar ownership is associated with approximately a $10.1 \%$ lower return on equity. This evidence is inconsistent with the view that CEOs took exposures that were not in the interests of shareholders. Rather, this evidence suggests that CEOs took exposures that they felt were profitable for their shareholders ex ante but that these exposures performed very poorly ex post. The convexity introduced by options does not appear to have had an adverse impact on accounting performance measured by ROE or by ROA. '

An important issue with our approach is that CEOs could have sharply decreased their holdings after 2006 but before the full impact of the crisis, so that they did not have to bear the cost of the exposures they took. In that case, they would have appeared to have incentives aligned with those of the other shareholders in 2006, but they would have traded out of these incentives or would have 
hedged them. Consequently, their behavior in 2006 might have been based on their knowledge that they would trade out of these incentives before the value of their portfolio fell substantially. For such a strategy to make sense, CEOs would have had to be able to anticipate the crisis. We investigate the insider trading of bank CEOs in 2007-2008. We find no evidence that they traded out of their positions. CEOs therefore had to bear the losses associated with the poor outcomes of the exposures their banks had at the end of 2006. Our evidence on CEO trading of shares in 2007 and 2008 is consistent with the hypothesis that the crisis and its evolution were unexpected for bank top executives. Some might argue that they should have known better, but our evidence also shows that they had stronger incentives than most to understand the distribution of the return of their stock and of the overall performance of their bank.

There is a long literature on the compensation of bank CEOs. This literature shows that CEO compensation depends on stock return and accounting performance (Barro and Barro (1990)) as does the compensation of CEOs generally, but also that the composition of pay differs for bank CEOs from CEOs of other industries. In particular, the share of pay in the form of stock and options for bank CEOs is lower than in other industries (e.g., Adams and Mehran (2003) or Houston and James (1995)). Several papers investigate the impact of deregulation and greater competition on bank CEO compensation. In particular, Hubbard and Palia (1995) and Crawford, Ezzell, and Miles (2003) conclude that deregulation led to greater pay-for-performance sensitivity of CEO pay at banks. Further, Crawford, Ezzell, and Miles (2003) find that, following deregulation, pay-for-performance sensitivity of CEO pay increased more at less well-capitalized institutions. They interpret this result as evidence of a moral hazard problem induced by the existence of deposit insurance priced in a way that does not reflect the risks taken on by individual banks.

More recently, a series of papers has analyzed whether bank CEO compensation is optimally designed to trade off two types of agency problems: the standard managerial agency problem as well as the risk-shifting problem between shareholders and debtholders that may be particularly 
severe in highly leveraged institutions (e.g., John, Mehran and Qian (2008) and John and Qian (2003)). These papers also argue that leverage should reduce the pay-for-performance sensitivity of bank CEOs compared to other CEOs because of monitoring by debtholders. Accordingly, John and Quian (2003) show that bank CEOs have lower pay-for-performance sensitivity than other CEOs. This literature emphasizes that it may be optimal for shareholders to take more risks because doing so increases the value of the put granted to banks by the FDIC. According to this literature, aligning the incentives of CEOs better with those of shareholders may increase rather than decrease systemic risk. John, Saunders, and Senbet (2000) develop a model in which it is optimal for the FDIC to set insurance premiums taking into account the compensation contract of the bank's CEO.

The paper proceeds as follows. In Section 1, we introduce our sample of banks. In Section 2, we present data on CEO compensation and equity ownership at the end of fiscal year 2006 . We then turn to the relation between CEO compensation, equity ownership, and bank performance during the crisis in Section 3. In Section 4, we investigate the trading of CEOs in shares of their own bank after the end of 2006 and how their equity ownership evolves during the crisis. We conclude in Section 5.

\section{The sample of banks}

Our study requires compensation data. This data is available through Standard and Poor's Execucomp database. We use that database as the starting point for the formation of our sample. We download all firm-year observations for firms with SIC codes between 6000 and 6300 in fiscal year 2006. This yields 132 unique firms. We exclude firms with SIC codes 6282 (Investment Advice), because these are not in the lending business (e.g., Janus, T Rowe Price). In addition, we

manually go through the list of firms in SIC codes 6199 (Finance Services) and SIC code 6211 (Security Brokers and Dealers). Such a manual search is necessary because SEC code 6211 
includes not only investment banks but also pure brokerage houses such as Charles Schwab. ${ }^{5}$ Further, SIC code 6199 contains both American Express and Citigroup. Though our sample has investment banks, we exclude pure brokerage houses and also report tests that exclude investment banks. For increased transparency, we show the firms we exclude from our analysis and those we include in Appendices A and B. Our final raw sample contains 98 firms. In addition, we obtain accounting data from Compustat, additional banking data from Compustat Bank, insider trading data from Thomson Financial, and stock return data from CRSP.

Table 1 provides summary statistics of our sample of banks. It shows that we cover very large financial institutions. This is not surprising since Execucomp is biased towards larger firms. The median asset value is $\$ 15.5$ billion, and the mean asset value is $\$ 129.3$ billion. The sum of total assets of sample firms at the end-of-fiscal year 2006 is $\$ 12.3$ trillion. At the end of 2006, the average (median) market capitalization of sample banks is $\$ 18.7$ billion ( $\$ 2.8$ billion). The average net income over assets (over equity) is $1.2 \%(13.5 \%)$. We also report two measures of capital strength, the tier 1 capital ratio and the tangible common equity divided by tangible assets. The Tier 1 capital ratio is on average $9.7 \%$, while the tangible common equity ratio is $6.7 \%$ at the end of fiscal year 2006. On average, the Tier 1 capital ratio makes these banks well capitalized. The lowest Tier 1 ratio is $5.73 \%$, which is substantially above the regulatory minimum of $4 \%$. No bank in our sample has negative net income in 2006.

Our study examines the accounting and stock return performance of the sample banks until the end of 2008. Table 2 shows the attrition of sample firms from fiscal year end 2006 to the end of 2008. Of the 95 banks with complete CEO compensation data in 2006, 77 survived until December 2008. 12 banks were acquired, and 6 banks delisted from the exchange due to a violation of listing requirements or bankruptcy.

\footnotetext{
${ }^{5}$ Using the finer North American Industry Classification System (NAICS) does not resolve the issues. For example, Goldman Sachs Group is classified as 523110 (Investment Banking \& Brokerage) while Bear Stearns is classified as 523120 (Securities Brokerage).
} 


\section{CEO compensation and equity ownership at the end of fiscal year 2006}

We now turn to an examination of CEO's compensation and of their equity and option holdings at the end of 2006. Table 3 provides summary statistics on CEOs' equity position and compensation. The Table has 95 observations because three firms do not report CEO equity holdings for 2006 as a result of a change in CEO. Starting with fiscal year 2006, FASB 123(R) changed the way executive compensation is reported in proxy statements. For example, it introduced finer reporting requirements for deferred compensation, pension benefits, and details on all option series held by executives. The latter change greatly facilitates the calculation of the sensitivity of the executive's option portfolio to volatility and stock price changes.

The total compensation (including new option and stock grants, but excluding gains from exercising options) of sample CEOs was on average $\$ 7.9$ million, and the median compensation was $\$ 2.5$ million. The majority of CEO compensation stems from performance-based pay, as the average base salary of $\$ 760,000$ is less than $10 \%$ of the average total compensation. John and Qian (2003) use a sample constructed similarly to ours and investigate compensation for 120 commercial banks from 1992 to 2000 . In that study, they find that the ratio of average salary to average total direct compensation is higher than what we find (16\% versus $10 \%)$. Annual bonuses are paid both in cash for achievements of accounting based goals, and in equity to align incentives of CEOs and shareholders. More than $70 \%$ of all CEOs receive at least some of their 2006 compensation in equity. Conditional on at least receiving some compensation in equity, the fraction of equity pay is on average $48.5 \%$. The dollar value of the annual equity grants is $\$ 4.3$ million on average.

As Hall and Liebman (1998) and Core and Guay (1999) point out, most CEO equity incentives stem from the existing portfolio of stock and options, and not from annual grants. A similar result holds for our sample. We define the total dollar value of equity of a CEO at the end of fiscal year 2006 as the sum of unrestricted and restricted shares held multiplied by the end-of-year share price 
plus the FASB 123R fair value (where available) ${ }^{6}$ or Black-Scholes value of exercisable and unexercisable stock options plus the fair value of unearned equity incentive plans. The mean (median) value of the CEO's equity stake is $\$ 88.1$ million ( $\$ 36.3$ million). The average value of the overall equity portfolio is 20 times larger than the dollar value of annual grants of stocks and options (\$2.6 million $+\$ 1.6$ million) and more than ten times larger than the CEO's total annual compensation. Perhaps surprisingly, much of the equity of the CEO is held voluntarily through unrestricted stock and vested, exercisable options. ${ }^{7}$ There are 20 CEOs in our sample that have equity stakes valued at more than $\$ 100$ million. The top 5 equity positions at the end of fiscal year 2006 are held by Richard Fuld (Lehman Brothers, \$1,003 million), James Cayne (Bear Stearns, \$953 million), Stan O’Neal (Merrill Lynch, \$359 million), John Mack (Morgan Stanley, \$320 million), and Angelo Mozilo (Countrywide Financial, \$285 million). On average, the shares owned by CEOs in our sample correspond to $1.6 \%$ of the shares of the company. In their sample, John and Qian (2003) found average equity holdings of $1.3 \%$ for their sample of commercial banks.

We use the detailed option plan table to calculate the delta and vega of each option grant (current and past grants). To calculate delta and vega, we need the option's exercise price, expiration date, volatility, the current stock price, the relevant interest rate, and the dividend yield. Option exercise price and expiration date come directly from Execucomp. We use the fiscal yearend closing price of 2006 as the current stock price, the 3-year lagged volatility at the end of 2006 as an estimate of the volatility, and the annual cash dividend for 2006 divided by the fiscal-year end closing price as an estimate of the dividend yield. The 10-year treasury rate is used as an estimate of the risk-free interest rate.

\footnotetext{
${ }^{6}$ Fair values need to be reported according to FASB 123R, but the new format only became mandatory starting 12/31/2006, so that firms that have a fiscal year end not equal to December will report according to the old rules in our data. There are a total of 7 firms that do not report these values. For those firms, we use the aggregate values given for the exercisable and unexercisable options.

${ }^{7}$ Some companies may have established target stock ownership plans for their executives, so that the executive is not free to sell his or her entire stake (see, e.g., Core and Larcker (2002)).
} 
Table 3 presents two measures of sensitivity of the equity portfolio of the CEO. We show that the average (median) CEO has an ownership from shares and delta-weighted options of $2.4 \%$ (1.1\%). In other words, the CEO's wealth increases by $\$ 24(\$ 11)$ for every $\$ 1,000$ in created shareholder wealth. The second measure is the dollar gain for a $1 \%$ increase in shareholder value. Table 3 shows that the average dollar gain is $\$ 1.1$ million for a $1 \%$ change in firm value.

We calculate the percentage change in the equity portfolio value of a CEO for a one percent increase in volatility using options only. We call this measure percentage equity risk sensitivity. Although common stock has some exposure to volatility (because it can be considered as a call option), Guay (1999) shows that for the typical firm, the volatility exposure of common stock is negligible. This result may not apply to banks because they are highly levered. Nevertheless, we use the traditional approach to estimate the equity risk sensitivity since its interpretation is well understood. It is possible that by proceeding this way we understate the equity risk sensitivity of CEOs. The average CEO in our sample stands to gain $0.5 \%$ of his total portfolio value if the stock price volatility increased by $1 \%$. Alternatively, we can estimate the change in the dollar value of the CEO's wealth for a $1 \%$ increase in stock price volatility. We call this measure the dollar equity risk sensitivity. In our sample, the average dollar equity risk sensitivity is $\$ 187,000$. A risk-averse CEO would have to trade off the monetary value of an increase in volatility against its impact on the volatility of his wealth.

\section{CEO incentives and bank performance during the crisis}

In this section, we investigate the relation between CEO incentives as of the end of fiscal year 2006 and bank performance during the crisis. For the purpose of this paper, we consider the returns of banks from July 1, 2007, to December 31, 2008, to correspond to the returns of these banks during the crisis period. Admittedly, the crisis did not end in December 2008. Bank stocks lost substantial ground in the first quarter of 2009. However, during the period we consider the banking sector suffered losses not observed since the Great Depression. The subsequent losses were at least 
partly affected by uncertainty about whether banks would be nationalized. Since it is not clear how the impact on bank stocks of the threat of nationalization would be affected by the incentives of CEOs before the crisis, it may well be that it is better to evaluate returns only until the end of 2008 .

There is a longstanding debate in the corporate finance literature on how to assess long-run performance (see Fama (1998) and Ritter and Loughran (2000)). One approach is to construct portfolios and evaluate the abnormal performance of these portfolios from the intercept of regressions of the returns of the portfolios on known risk factors. This approach has the advantage of evaluating performance in the context of a portfolio strategy. Another approach is to use buyand-hold returns. Using buy-and-hold returns is generally a better approach when attempting to explain the cross-sectional variation in performance when performance can be affected by many factors. In this paper, we use both approaches.

Our first approach to estimate the relation between bank stock returns and bank CEO incentives is to construct portfolios of banks that differ in CEO incentives and to compare the excess returns of these portfolios. We have four measures of incentives. The first two measures are percentage ownership and dollar ownership. The last two measures are percentage equity risk sensitivity and dollar equity risk sensitivity.

We first construct portfolios of banks that, respectively, are in the top quartile and the bottom quartile of percentage ownership. In Panel A of Table 4, we report the mean weekly raw return and the median weekly raw return of a portfolio that is long the top quartile portfolio and short the bottom quartile portfolio. A negative return for the long-short portfolio means that the banks with CEOs who have the highest percentage ownership fared more poorly than the banks with CEOs who have the lowest percentage ownership. We find that the mean and median raw returns are insignificantly negative. The same result holds when we use dollar ownership instead of percentage ownership (row 2). Figure 1 plots the cumulative weekly raw returns of the portfolio that is long banks with CEOs in the top quartile of dollar ownership and short banks with CEOs in the bottom quartile of dollar ownership starting on July 1, 2007. The figure shows that the high ownership 
portfolio underperforms the low ownership portfolio. While the effects are statistically insignificant in Table 4, Figure 1 is suggestive of economically large return differences. We also construct extreme quartile portfolios for percentage equity risk sensitivity and dollar equity risk sensitivity. The portfolio long the banks in the top quartile and short the banks in the bottom quartile of percentage equity risk sensitivity has a positive insignificant average and median return. In the case of dollar equity risk sensitivity, the mean and median returns are indistinguishable from zero.

Panel B of Table 4 estimates the Fama and French (1993) model for each of the four portfolio strategies. This approach controls for factors known to affect returns of portfolios. The first row provides results for the high minus low percentage ownership portfolio. The intercept of the regression (alpha) is $-0.62 \%$ per week and statistically insignificant. In other words, a portfolio long the banks where the CEO has high equity incentives in the form of high share percentage ownership and short the banks where the CEO has low equity incentives underperforms, but not significantly so. We also estimated the same model starting on January 1,2007 . If we do that, the intercept is -0.0067 and is significant at the $10 \%$ level. The advantage of using the longer sample period is that the number of observations increases by a third, but at the cost that we include some months that precede the credit crisis to estimate the model more precisely. The regression for dollar ownership is presented next. With that regression, the intercept is again negative and not significant. It is interesting to note that the percentage ownership portfolio strategy and the dollar ownership portfolio strategy have very different exposures to the risk factors. In the case of the percentage ownership portfolio strategy, the firms with high percentage ownership CEOs are less exposed to the market portfolio and more exposed to the SMB portfolio (which is the return of small firms minus the return of large firms). The opposite is true for the dollar ownership portfolio. This suggests that firms with high percentage equity ownership are smaller firms, whereas perhaps not surprisingly the firms with high dollar ownership are larger firms. We then turn to the equity risk sensitivity incentive regressions. With the regression that uses percentage equity risk sensitivity, the intercept is positive and insignificant. This coefficient is positive and significant if 
we estimate the model starting on January 1, 2007. The final regression uses the dollar equity risk sensitivity. For that regression, the intercept is also indistinguishable from zero. Again, the firms with more dollar equity risk sensitivity appear to be larger firms.

Table 4 shows that there is no evidence that banks with higher CEO ownership performed better during the crisis and no evidence that banks where the risk incentives resulting from option holding were higher performed worse. With the longer sample period, there is evidence that banks with higher CEO ownership performed worse. The advantage of the approach used in that table is that it evaluates returns on portfolios that investors could have held. However, by forming portfolios, we cannot use much information about individual banks. We now turn to tests that exploit more information about individual banks.

We investigate the determinants of returns of individual banks using multiple regressions of buy-and-hold returns of banks from July 1, 2007, to December 31, 2008, on various bank characteristics. ${ }^{8}$ The first four regressions respectively use each one of our incentive measures. Our other determinants of stock performance are the performance of the bank's stock in 2006, the equity book-to-market ratio, and the log of the bank's market value. Past returns, the book-tomarket ratio, and the log of market value are all variables known to be related to returns. However, here, these variables could affect performance for other reasons than for their role as risk factors that affect expected returns. For instance, it could be that larger banks were able to take more risks. A $\log$ transformation is applied to both the percentage ownership and the percentage vega. This transformation reduces the influence of extremely high values of these variables and makes the distribution closer to the normal distribution (e.g., Demsetz and Lehn (1985) and Himmelberg, Hubbard, and Palia (1999)). We winsorize the dollar incentive measures at the $2^{\text {nd }}$ and $98^{\text {th }}$ percentile. Regression (1) uses the logarithm of dollar ownership. The coefficient on dollar ownership is significantly negative. The coefficient on percentage ownership in regression (2) is

\footnotetext{
${ }^{8}$ Proceeds from banks that delist or merge prior to December 2008 are put in a cash account until December 2008. Results are qualitatively and quantitatively similar if proceeds are put in an industry index.
} 
negative as well but not significant. We also estimated this regression without the $\log$ transformation, in which case the coefficient on percentage ownership is negative and marginally significant. However, the significance is driven by a few large values and disappears when we winsorize percentage ownership at the $5 \%$ level. We then turn to equity risk incentives. Regression (3) uses the dollar measure. The coefficient is negative and insignificant. In regression (4), the coefficient on the percentage measure is positive and significant.

In regressions (5) and (6), we use respectively dollar and percentage incentive measures and control for other determinants of performance measured as of the end of 2006. In regression (5), the dollar share ownership has a negative significant coefficient. This effect is economically significant. The standard deviation of the logarithm of dollar equity incentives is 1.6. Consequently, an increase of one standard deviation in dollar ownership is associated with lower returns of $10.2 \%(0.064 \times 1.6)$. Also, a bank's return during the crisis is negatively related to the bank's stock return performance in 2006, although the result is not statistically significant. Beltratti and Stulz (2009) also find this result - but with statistical significance - for a sample of international banks. This result suggests that banks that took on more exposures that the market approved of in 2006 suffered more during the crisis. We find next that banks with a higher book-tomarket ratio in 2006 have worse performance during the crisis. A possible explanation for this result is that banks with less franchise value took more risks that worked out poorly during the crisis. Large banks perform worse. Turning to regression (6), percentage ownership has a negative insignificant coefficient and percentage equity risk incentive has a positive significant coefficient. The coefficients on the other explanatory variables are similar to those of regression (5). Regressions (7) and (8) require information on the Tier 1 capital ratio of banks. This requirement removes from the sample all non-depository banks. In particular, all large investment banks drop out of the sample. The coefficients on the incentive variables of CEOs are largely the same. It follows therefore that our results cannot be explained by the large share ownership of some CEOs of investment banks that performed poorly. 
The results of Table 5 are robust when we change the sample period or variables. In regressions not reproduced here, we use tangible common equity to assets as a measure of the capital ratio and obtain similar results. We also find similar results if we use returns from January 1, 2007, to December 31,2008 , or if we use only 2008. The same results hold if we do not winsorize dollar incentives or if we truncate dollar incentives.

So far, we have focused on bank performance measured by equity returns. We now turn to the performance of banks using two measures of accounting performance: Return on assets (ROA) and return on equity (ROE). In Figure 2, we show the evolution of quarterly ROA from 2005Q4 to 2008Q3. Not surprisingly, the average ROA plummets in 2008. For our regression analysis, return on assets is defined as the cumulative quarterly net income from 2007Q3 to 2008Q3 divided by total assets at the end of 2007Q2. For return on equity, we divide the cumulative quarterly net income by the book value of equity at the end of 2007Q2. In the regressions we report in Table 6, we use the same control variables as those used in Table 5. Regressions (1) through (4) use ROA as the dependent variable. The first two regressions use all banks; the last two regressions require availability of the Tier 1 capital ratio. In the sample of all banks, neither the CEO's dollar incentive measure nor his percentage ownership measure has a significant coefficient. With the equity risk sensitivity measure, neither the dollar measure nor the percentage measure is significant. In regressions (3) and (4), the only change for the CEO incentive measures is that the CEO's dollar incentive measure has a significant negative coefficient. The only other explanatory variable that is significant in the regressions is the book-to-market ratio. Turning to the four ROE regressions, we see that the CEO's dollar incentive measure has a negative significant coefficient in both regressions. In regression (7), which uses a sample of depository banks only, the percentage ownership measure has a negative significant coefficient. The percentage risk sensitivity measure is significant in regression (5) but, although the coefficient is similar, it is not in regression (7) that uses a smaller sample. The dollar risk sensitivity measure is significant in the larger sample, but not 
in the smaller one. In addition to book-to-market, the lagged return is now significant in regressions (5) and (6).

We estimate other regressions using ROA and ROE that we do not reproduce in a table. First, we estimate regressions where the additional explanatory variables besides the CEO incentive measures are the log of the bank's market value at the end of 2006, the volatility of its stock return in the three previous years, and the Tier I capital ratio. We find that the coefficient on dollar equity incentives is negative and significant in the ROE regression. The coefficient on volatility is negative and significant. We also estimate these regressions on changes in ROA and changes in ROE. The dollar equity incentive has a significant negative coefficient and the dollar equity risk sensitivity measure has a positive significant coefficient.

\section{CEO equity losses during the crisis}

We have uncovered no evidence supportive of the view that better alignment of incentives between CEOs and shareholders would have led to better bank performance or that option compensation is to blame for the poor performance of banks. Our evidence is consistent with the hypothesis that CEOs who took exposures that performed poorly during the crisis did so because they thought that doing so was good for shareholders as well as for themselves. Our evidence provides no support for the hypothesis that option compensation led CEOs to take on more exposures that performed poorly during the crisis. Finally, our evidence is consistent with the hypothesis that CEOs did not expect these exposures to work out poorly.

So far, however, we proceeded with our analysis using CEO share and option holdings at the end of 2006. If CEOs saw the crisis coming some time after the end of 2006, they could have sold their holdings and hence would not have been affected adversely by their decisions. We investigate in this section how share ownership of CEOs evolved during the crisis. For this analysis, we use Execucomp and the database on insider transactions from Thomsom Financial. We aggregate CEO 
transactions by firm and quarter. We are able to match 88 of the 95 bank CEOs in Execucomp to the Thomson Financial database.

Figure 3 reports the quarterly mean and median of CEO net share purchases between 2007Q1 and 2008Q4. Throughout the period, on average, CEOs sell less than $2 \%$ of their holdings per quarter. The exception is for the quarter ending in September 2008, when they sell almost $4 \%$ of their holdings on average. It is common for executives to sell shares because their portfolio tends to become less diversified as they exercise options and receive stock grants. Figure 3 also shows the increase in ownership of CEOs through new grants of options and stock. They receive grants throughout the period.

In Table 7, we attempt to estimate the dollar loss of CEOs in our sample on their stock holdings resulting from the fall in the value of their holdings over the period from the end of fiscal year 2006 through December 31, 2008. Our starting point for each CEO is the shares held at the end of 2006. We then use the insider trading data to evaluate the price at which the CEO sold shares if he sold shares. The CEO's loss is then defined as the loss in value of the shares not sold, evaluated using the price of the shares at the end of December 2008 or when the CEO loses his job plus the loss made on shares sold, measured as the difference between the value of shares at the end of 2006 and the price of the shares sold. The average value of shares held at the end of 2006 is \$61.503 million. On average, a CEO lost \$28.771 million on the shares not sold and \$2.719 million on the shares sold. More than three quarters of the CEOs did not report any insider sales. On average, a CEO lost $\$ 31.490$ million. The median loss is sharply less, however, at $\$ 5.084$ million. It follows from Table 7 that CEOs made large losses on their wealth during the crisis and that most of these losses come from holding on to their shares. Had CEOs seen the crisis coming, they could have avoided most of these losses by selling their shares. They clearly did not do so.

We also investigate what happened to the options held by CEOs. Strikingly, only $12 \%$ of the options granted before 2007 were out of the money at fiscal year end 2006. In contrast, 
approximately $70 \%$ of all options granted before 2007 were out of the money at the end of the sample period. Consequently, CEOs suffered large losses on their options as well.

A valid concern is whether we overestimate the equity losses of insiders. We could be missing hedging activities by insiders that are carried out through off-market equity transactions such as zero-cost equity collars, exchange funds, or variable prepaid forward contracts. ${ }^{9}$ All these transactions have in common that the insider does not sell the shares and thus retains the voting rights of the stock while receiving significant downside protection.

It is important to note that the SEC has mandated reporting of such hedging transactions since 1996. Thomson Financial, our data provider for insider transactions, has specific fields that capture trading of prepaid variable forward contracts, exchange funds, and equity swaps. When we search for zero-cost collars, exchange funds, and prepaid variable forward contracts by the CEOs of sample banks, we do not find a single hedging transaction. When we expand the search to all bank insiders between January 2007 and December 2008, we find less than 10 transactions, mostly prepaid variable forward contracts by non-executive directors.

The lack of reported hedging activities is not surprising in light of the sample sizes of two comprehensive studies on off-market equity transactions. Bettis, Bizjak, and Lemmon (2001) study all filings by all insiders between January 1996 and December 1998 and are only able to identify 85 zero-cost collars. Jagolinzer, Matsunaga, and Yeung (2007) examine prepaid variable forward transactions and are able to find only 174 contracts from the universe of filings between August 1996 and June 2004, with roughly a third of them carried out by CEOs.

While there is some debate on the issue of whether insiders underreport hedging transactions, it is argued by most legal experts that not reporting hedging transactions is illegal (see the discussion in Smith and Eisinger (2004)). Overall, we have no reason to believe that significant hedging activities attenuate the finding of large equity losses documented in Table 7.

\footnotetext{
${ }^{9}$ The use of equity swaps disappeared in the mid-nineties because of their disadvantageous tax treatment.
} 


\section{Conclusion}

Bank CEO incentives cannot be blamed for the credit crisis or for the performance of banks during that crisis. Whether we look at depository banks only or at a larger sample that includes investment banks as well, there is no evidence that banks with CEOs whose incentives were less well aligned with the interests of their shareholders performed worse during the crisis. When we attempt to explain the performance of banks in the cross-section, we find evidence that banks where CEOs had better incentives in terms of the dollar value of their stake in their bank performed significantly worse than banks where CEOs had poorer incentives. Stock options had no adverse impact on bank performance during the crisis.

A possible explanation for our results is that CEOs with better incentives to maximize shareholder wealth took risks that other CEOs did not. Ex ante, these risks looked profitable for shareholders. Ex post, these risks had unexpected poor outcomes. These poor outcomes are not evidence of CEOs acting in their own interest at the expense of shareholder wealth.

Support for this possible explanation is provided by our examination of the wealth consequences of the crisis for bank CEOs. If CEOs took risks that they knew were not in the interests of their shareholders, we would expect them to have sold shares ahead of the crisis. We find that this did not happen. In fact, CEO holdings of shares on net increased. Not surprisingly, CEOs therefore made large losses on their holdings of shares and on their holdings of options. On average, CEOs in our sample lost at least $\$ 30$ million and the median CEO loss is more than $\$ 5$ million. 


\section{References}

Adams, Renée, and Hamid Mehran, 2003, Is corporate governance different for bank holding companies?, Federal Reserve Bank of New York Economic Policy Review 9, 123-142.

Barro, Jason R., and Robert J. Barro, 1990, Pay, performance, and turnover of bank CEOs, Journal of Labor Economics 8, 448-481.

Bebchuck, Lucian A., and Holger Spamann, 2009, Regulating bankers' pay, working paper, John M. Olin Center for Law, Economics, and Business, Harvard University, Cambridge, MA.

Beltratti, Andrea, and René M. Stulz, 2009, Why did some banks perform better during the credit crisis? A cross-country study of the impact of governance and regulation, unpublished working paper, Ohio State University, Columbus, $\mathrm{OH}$.

Bettis, J. Carr, Bizjak, John M., and Michael L. Lemmon, 2001, Managerial ownership, incentive contracting, and the use of zero-cost collars and equity swaps by corporate insiders, Journal of Financial and Quantitative Analysis 36, 345-370.

Core, John E., and Wayne Guay, 1999, The use of equity grants to manage optimal equity incentive levels, Journal of Accounting \& Economics 28, 151-184.

Core, John E., and David F. Larcker, 2002, Performance consequences of mandatory increases in executive stock ownership, Journal of Financial Economics 64, 317-340.

Crawford, Anthony J., John R. Ezzell, and James A. Miles, 1995, Bank CEO pay-performance relations and the effects of deregulation, Journal of Business 68, 231-256.

Demsetz, Harold, and Kenneth Lehn, 1985, The structure of corporate ownership: Causes and consequences, Journal of Political Economy 93, 1155-1177.

Fama, Eugene F., 1998, Market efficiency, long-term returns, and behavioral finance, Journal of Financial Economics 49, 283-306.

Fama, Eugene F., and Kenneth R. French, 1993, Common risk factors in the returns on bonds and stocks, Journal of Financial Economics 33, 3-53. 
Guay, Wayne, 1999, Compensation, convexity, and the incentives to manage risk: An empirical analysis, Journal of Financial Economics 53, 43-71.

Hall, Brian J., and Jeffrey B. Liebman, 1998, Are CEOs really paid like bureaucrats? Quarterly Journal of Economics 113, 653-691.

Himmelberg, Charles P., R. Glenn Hubbard, and Darius Palia, 1999, Understanding the determinants of managerial ownership and performance, Journal of Financial Economics 53, 333-384.

Houston, Joel F., and Christopher James, 1995, CEO compensation and bank risk: Is compensation in banking structured to promote risk-taking? Journal of Monetary Economics 36, 405-431.

Hubbard, R. Glenn, and Darius Palia, 1995, Executive pay and performance: Evidence from the U.S. banking industry, Journal of Financial Economics 39, 105-130.

Jagolinzer, Alan D., Matsunaga, Steven R., and Eric Yeung, 2007, An analysis of insiders' use of prepaid variable forward transactions, Journal of Accounting Research 45, 1055-1079.

John, Kose, Hamid Mehran, and Yiming Qian, 2008, Outside monitoring and CEO compensation in the banking industry, unpublished working paper, New York University, New York, NY.

John, Kose, and Yiming Qian, 2003, Incentive features in CEO compensation in the banking industry, Federal Reserve Bank of New York Economic Policy Review 9, 109-121.

John, Kose, Anthony Saunders, and Lemma W. Senbet, 2000, A theory of bank regulation and management compensation, The Review of Financial Studies 13, 95-112.

Loughran, Tim and Jay R. Ritter, 2000, Uniformly least powerful tests of market efficiency, Journal of Financial Economics 55, 361-389.

Smith, Randall, and Jesse Eisinger, 2004, The insiders' magic way to sell - SEC investigates securities firms that used derivatives contracts to help executives trade quietly, Wall Street Journal, March 19 2004. 


\section{Appendix A: List of excluded financial firms in SIC codes 6000 - 6300}

We download all firms that are in Standard and Poor's Execucomp database in 2006 and have an SIC code between 6000 and 6300. From this list, we exclude the following firms because they are mostly concerned with investment advice, pure brokerage business, or wire transfering and do not match well our definition of a lending institution:

A G Edwards

Affiliated Managers Group Inc.

American Express

Americredit Corp

Bankrate Inc.

Bisys Group

Capital One Financial

Charles Schwab

CIT Group

CME Group

Eaton Vance Corporation

E-Trade Financial Group

Federated Investors Inc.

Financial Federal Corporation

Finova Group

Franklin Resources Inc

Intercontinental Exchange

Investment Technology Group

Janus Capital Group Inc

LaBranche \& Co

Legg Mason Inc

Mellon Financial Corp

Metavante Technologies

Moneygram International

Nuveen Investments

Price (T Rowe) Group

Raymond James Financial

SEI Investments Company

Southwest Securities Group (SWS Group)

State Street Corporation

TD Ameritrade Holding

Tradestation group

Waddell\&Reed 


\section{Table 1: Sample summary statistics for calendar year 2006}

The table shows summary statistics for key variables for a sample of 95 bank holding companies and investment banks for fiscal year 2006. Sample selection criteria are described in Section 2. The list of sample banks is provided in Appendix B. The data are from the Compustat annual and Compustat Bank annual databases. Tier 1 capital ratio is calculated according to the Basle Accord for reporting risk-adjusted capital adequacy and is taken from the Compustat Bank database. The tangible common equity ratio is defined as tangible common equity divided by total assets less intangible assets (including goodwill). Those data are provided by the Compustat annual database.

\begin{tabular}{lcrrrrrrr} 
& \multicolumn{2}{c}{ Lower } & \multicolumn{2}{l}{ Upper } \\
& N & Minimum & Quartile & \multicolumn{1}{c}{ Median } & Quartile & Maximum & Mean & Std Dev \\
\hline Total assets & 95 & 2008.5 & 6717.6 & 15497.2 & 60712.2 & 1459737.0 & 129307.2 & 303878.5 \\
Total liabilities & 95 & 1788.8 & 6083.5 & 14685.0 & 56768.3 & 1324465.0 & 119265.6 & 280902.5 \\
Market capitalization & 94 & 366.5 & 1222.5 & 2788.4 & 13273.0 & 273598.1 & 18725.5 & 44489.8 \\
Net income / total assets & 95 & $0.03 \%$ & $0.84 \%$ & $1.16 \%$ & $1.45 \%$ & $2.55 \%$ & $1.17 \%$ & $0.47 \%$ \\
Net income / book equity & 95 & $0.33 \%$ & $10.42 \%$ & $13.01 \%$ & $16.63 \%$ & $29.18 \%$ & $13.46 \%$ & $5.67 \%$ \\
Cash / total assets & 95 & $0.38 \%$ & $1.63 \%$ & $2.26 \%$ & $2.79 \%$ & $6.47 \%$ & $2.35 \%$ & $1.20 \%$ \\
Dividend per share & 95 & 0.00 & 0.45 & 0.88 & 1.30 & 2.32 & 0.93 & 0.58 \\
Book-to-market ratio & 94 & 0.27 & 0.43 & 0.50 & 0.64 & 0.87 & 0.53 & 0.15 \\
Tier 1 capital ratio & 83 & $5.73 \%$ & $8.43 \%$ & $9.42 \%$ & $11.09 \%$ & $19.04 \%$ & $9.70 \%$ & $2.00 \%$ \\
Tangible common equity & & & & & & & & \\
ratio & 83 & $1.63 \%$ & $5.32 \%$ & $6.36 \%$ & $7.40 \%$ & $22.91 \%$ & $6.69 \%$ & $2.73 \%$
\end{tabular}




\section{Table 2: Attrition of banks included in sample}

The sample includes 95 commercial and investment banks covered by Execucomp in fiscal year 2006. Remaining in sample signifies that the bank is still listed on a major U.S.

exchange in December 2008. Merged or acquired signifies that the bank left the sample due to an acquisition or merger during the sample period, and Delisted by exchange signifies a delisting of the bank due to a violation of listing requirements or bankruptcy.

\section{$\underline{\text { Event }}$}

Remaining in sample

Merged or acquired

Delisted by exchange

\section{Number of Obs. $\quad$ Frequency [\%]}

77

81.1

12

12.6

6

6.3 


\section{Table 3: CEO compensation and equity ownership at the end of fiscal year 2006}

The table shows summary statistics for key compensation variables for a sample of 95 bank holding companies and investment banks for fiscal year 2006. The data are from the Compustat Execucomp database. Values are reported in thousands of dollars. Most of the variables of the table are directly taken from Execucomp. The percentage change in portfolio value for a $1 \%$ increase in volatility is calculated using the detailed information on all current and previous option grants mandated by FASB 123R. Percentage ownership from shares and exercisable options is from the proxy statement and counts exercisable options and options that become exercisable within 60 days after the record date as the equivalent of 1 share. Percentage ownership from shares and all options (delta-weighted) uses the detailed information on current and previous option grants to calculate the options' delta and multiplies the number of options held in each series by its delta when calculating the percentage ownership.

\section{CEO annual compensation}

Total Compensation

Salary

Zero equity pay in total compensation

Fraction of total comp paid in equity

Dollar value of annual option grant

Dollar value of annual stock grant

CEO deferred compensation and pensions

Aggregate Balance of deferred compensation

Present value of all pension promises

Total debt CEO - firm

\section{CEO equity portfolio - value}

Value of equity stake

Value of exercisable options

Value of unexercisable options

Value of unvested restricted stock

Value of stock and options in CEO portfolio

\begin{tabular}{rrrrrr}
\multicolumn{5}{c}{ Lower } & \multicolumn{5}{c}{ Upper } \\
95 & Quartile & Median & Quartile & \multicolumn{1}{c}{ Mean } & \multicolumn{1}{c}{ std dev } \\
95 & 566.3 & 2503.8 & 7448.5 & 7874.2 & 11513.0 \\
95 & & & 978.5 & 764.1 & 344.8 \\
68 & $35.8 \%$ & $47.5 \%$ & $64.1 \%$ & $48.5 \%$ & $19.9 \%$ \\
95 & 0 & 205.9 & 1687.5 & 1624.3 & 3500.8 \\
95 & 0 & 314.3 & 2009.0 & 2680.6 & 6086.5
\end{tabular}

$\begin{array}{rrrrrr}91 & 0.0 & 714.0 & 5000.4 & 7351.4 & 23626.5 \\ 91 & 97.6 & 2221.5 & 6653.0 & 5497.3 & 8420.5 \\ 91 & 970.4 & 4253.4 & 11748.0 & 12848.6 & 26597.5\end{array}$

$\begin{array}{llllll}95 & 5046.5 & 22928.5 & 57548.3 & 57226.2 & 111345 .\end{array}$

$\begin{array}{rrrrrr}95 & 1452.2 & 5024.2 & 19456.6 & 16622.0 & 30910.1\end{array}$

$\begin{array}{llllrr}95 & 0.0 & 234.6 & 1533.0 & 1728.9 & 3907.4\end{array}$

$\begin{array}{llllll}95 & 0.0 & 242.1 & 3139.2 & 10782.8 & 55860.0\end{array}$

$\begin{array}{llllll}95 & 10363.3 & 36360.6 & 85039.9 & 88123.8 & 156104 .\end{array}$

\section{CEO equity portfolio - incentives}

Percentage ownership from shares

Percentage ownership from shares and all

options (delta-weighted)

Dollar change in portfolio value for $1 \%$ change

in firm value

$\begin{array}{rrrrrr}95 & 0.2 \% & 0.4 \% & 1.2 \% & 1.6 \% & 4.3 \% \\ 95 & 0.5 \% & 1.1 \% & 2.4 \% & 2.4 \% & 4.7 \% \\ 94 & 169.3 & 501.8 & 1376.2 & 1134.6 & 1586.6\end{array}$

\section{CEO exposure to equity risk}

Percentage change in portfolio value for a $1 \%$ increase in volatility

Dollar change in portfolio value for a $1 \%$

increase in volatility

94

94
$0.06 \%$

20.1

\begin{abstract}
$0.25 \%$
\end{abstract}
59.5
$0.59 \%$

211.8
$0.46 \%$

187.7
$1.01 \%$

287.9 


\section{Table 4: Returns to equal-weighted high and low ownership and equity risk portfolios}

Panel A of the table shows the average and median weekly return of a portfolio of high CEO ownership (high CEO equity risk) firms minus low CEO ownership (low CEO equity risk) firms. Firms are classified as high ownership (high equity risk) if the ownership (equity risk) of the CEO at the end of fiscal year 2006 is in the top quartile of all CEOs. Low ownership (low equity risk) is defined accordingly. The table reports results for a percentage ownership measure, which is equal to the number of shares and all options (delta-weighted) held by the CEO divided by the total number of shares outstanding as well as a dollar ownership measure, which is equal to the dollar change in the executive's portfolio for a $1 \%$ change in the stock price. Percentage equity risk is equal to the percentage change in the executive's equity portfolio value for a $1 \%$ change in volatility. Dollar equity risk is equal to the dollar change in the executive's portfolio value for a $1 \%$ change in volatility. In Panel A, p- and z-values of tests of statistical differences from zero are reported in parenthesis. Panel B reports estimates from a regression based on a three- factor performance attribution model for the weekly return difference of a high ownership (equity risk) minus low ownership (equity risk) portfolio. The panel reports equal-weighted weekly return regressions. The three factors are defined in Fama and French (1993). The factors are the returns to zero-investment portfolios designed to capture market (RMRF), size (SMB), and book-to-market (HML) effects, respectively. Standard errors are in parentheses. ***, **, and * indicate significance at the $1 \%, 5 \%$ and $10 \%$ levels, respectively.

Panel A: Weekly returns of high minus low CEO ownership/equity risk portfolios

\begin{tabular}{lllll} 
& Mean & p-value & Median & z-value \\
\hline $\begin{array}{l}\text { High minus low } \\
\text { \% ownership }\end{array}$ & -0.0041 & $(0.40)$ & -0.0023 & $(0.37)$ \\
$\begin{array}{l}\text { High minus low \$ } \\
\text { ownership }\end{array}$ & -0.0052 & $(0.28)$ & -0.0037 & $(0.19)$ \\
$\begin{array}{l}\text { High minus low } \\
\% \text { equity risk }\end{array}$ & 0.0038 & $(0.34)$ & 0.0065 & $(0.17)$ \\
$\begin{array}{l}\text { High minus low \$ } \\
\text { equity risk }\end{array}$ & -0.0014 & $(0.75)$ & -0.0001 & $(0.95)$
\end{tabular}

Panel B: Weekly Fama-French performance attribution regressions (Jul 2007-Dec 2008)

\begin{tabular}{lllll} 
& Alpha & RMRF & SMB & HML \\
\hline High minus low & -0.0062 & -0.161 & $1.166^{* * *}$ & $-0.714^{* *}$ \\
\% ownership & $(0.0043)$ & $(0.122)$ & $(0.305)$ & $(0.283)$ \\
High minus low \$ & -0.0018 & $0.362^{* * *}$ & $-0.951^{* * *}$ & $0.820^{* * *}$ \\
ownership & $(0.0037)$ & $(0.104)$ & $(0.261)$ & $(0.241)$ \\
High minus low & 0.0045 & $-0.170^{*}$ & $-0.960^{* * *}$ & $-0.864 * *$ \\
\% equity risk & $(0.0034)$ & $(0.098)$ & $(0.246)$ & $(0.227)$ \\
High minus low \$ & 0.0002 & $0.201^{*}$ & $-1.337^{* * *}$ & -0.193 \\
equity risk & $(0.0039)$ & $(0.107)$ & $(0.269)$ & $(0.249)$
\end{tabular}




\section{Table 5: Buy-and-hold returns and CEO ownership and equity risk exposure}

The Table shows results from a cross-sectional regression of buy-and-hold returns for banks from July 2007 - December 2008 on CEO equity ownership and firm characteristics measured at the end of fiscal year 2006. CEO equity ownership (dollar incentives) is the dollar change in the value of the CEO's equity portfolio for a $1 \%$ change in the stock price. CEO ownership (\%) is the sum of all shares (restricted and unrestricted) and delta-weighted options (exercisable and unexercisable) held by the CEO divided by the total number of shares outstanding multiplied by 100 . CEO \$ equity risk is defined as the dollar change in portfolio value for a $1 \%$ increase in volatility. CEO $\%$ equity risk is defined as the percentage change in portfolio value for a $1 \%$ increase in volatility and is calculated from all option series held by the CEO. A log transformation is applied to both the percentage ownership and percentage equity risk. The firm characteristics are measured at the end of year 2006. These characteristics include the stock return in 2006, the book-to-market ratio, the natural logarithm of the market capitalization, and the tier 1 capital ratio. Standard errors are reported in parentheses. Statistical significance at the 1\%, 5\%, and $10 \%$ level is indicated by $* * *, * *$, and $*$, respectively.

(1)

(2)

(3)

(4)

(6)

(8)

\begin{tabular}{|c|c|c|c|c|c|c|c|c|}
\hline CEO \$ ownership & $\begin{array}{l}-0.069 * * * \\
(0.025)\end{array}$ & & & & $\begin{array}{l}-0.064^{*} \\
(0.034)\end{array}$ & & $\begin{array}{l}-0.067^{*} \\
(0.037)\end{array}$ & \\
\hline CEO \% ownership & & $\begin{array}{l}-0.005 \\
(0.030)\end{array}$ & & & & $\begin{array}{l}-0.035 \\
(0.033)\end{array}$ & & $\begin{array}{l}-0.030 \\
(0.033)\end{array}$ \\
\hline CEO \$ equity risk & & & $\begin{array}{l}-0.005 \\
(0.018)\end{array}$ & & $\begin{array}{c}0.030 \\
(0.021)\end{array}$ & & $\begin{array}{c}0.040 \\
(0.025)\end{array}$ & \\
\hline CEO \% equity risk & & & & $\begin{array}{l}0.037 * * \\
(0.019)\end{array}$ & & $\begin{array}{c}0.024 \\
(0.019)\end{array}$ & & $\begin{array}{c}0.028 \\
(0.022)\end{array}$ \\
\hline Past stock return & & & & & $\begin{array}{l}-0.340 \\
(0.263)\end{array}$ & $\begin{array}{l}-0.347 \\
(0.266)\end{array}$ & $\begin{array}{l}-0.181 \\
(0.278)\end{array}$ & $\begin{array}{l}-0.205 \\
(0.281)\end{array}$ \\
\hline Book-to-market & & & & & $\begin{array}{l}-0.845^{* * * *} \\
(0.232)\end{array}$ & $\begin{array}{l}-0.838^{* * * *} \\
(0.233)\end{array}$ & $\begin{array}{l}-0.781 * * * \\
(0.241)\end{array}$ & $\begin{array}{l}-0.774 * * * \\
(0.243)\end{array}$ \\
\hline Log (market value) & & & & & $\begin{array}{l}-0.033 \\
(0.033)\end{array}$ & $\begin{array}{l}-0.068^{* * * *} \\
(0.024)\end{array}$ & $\begin{array}{c}0.010 \\
(0.034)\end{array}$ & $\begin{array}{l}-0.016 \\
(0.027)\end{array}$ \\
\hline Tier 1 capital ratio & & & & & & & $\begin{array}{c}0.047 * * \\
(0.019)\end{array}$ & $\begin{array}{l}0.048 * * \\
(0.019)\end{array}$ \\
\hline Number of observations & 94 & 94 & 93 & 93 & 89 & 89 & 78 & 78 \\
\hline Adjusted R2 & 0.069 & 0.017 & 0.001 & 0.030 & 0.25 & 0.25 & 0.30 & 0.29 \\
\hline
\end{tabular}




\section{Table 6: ROA and ROE regressions}

The Table shows regressions of the return on assets and return on equity on CEO ownership, CEO equity risk exposure, and control variables. Return on assets is defined as the cumulative quarterly net income from 2007Q3 to 2008Q3 divided by the total assets at the end of 2007Q2. Return on equity is defined as the cumulative quarterly net income from 2007Q3 to 2008Q3 divided by the book value of common equity at the end of 2007Q2. CEO \% ownership is the sum of all shares (restricted and unrestricted) and delta-weighted options (exercisable and unexercisable) held by the CEO divided by the total number of shares outstanding multiplied by 100 . CEO dollar ownership is the dollar change in the value of the CEO's equity portfolio for a $1 \%$ change in the stock price. CEO \% equity risk is defined as the percentage change in portfolio value for a $1 \%$ increase in volatility and is calculated from all option series held by the CEO. CEO dollar equity risk is defined as the dollar change in portfolio value for a $1 \%$ increase in volatility. A log transformation is applied to both the percentage ownership and percentage equity risk. Columns 1 through 4 show results for return on assets regressions, and columns 5 through 8 show corresponding results for the return on equity. The control variables include the natural logarithm of the market capitalization, the tier 1 capital ratio, and the book-to-market ratio, all measured at the end of fiscal year 2006. Lagged return is the lagged return on assets for columns 1 through 4 and the lagged return on equity for columns 5 through 8 . It is measured over the five previous quarters to be consistent. Standard errors are reported in parentheses. Statistical significance at the $1 \%, 5 \%$, and $10 \%$ level is indicated by $* * *, * *$, and $*$, respectively.

\begin{tabular}{|c|c|c|c|c|c|c|c|c|}
\hline & \multicolumn{4}{|c|}{ ROA } & \multicolumn{4}{|c|}{ ROE } \\
\hline & (1) & (2) & (3) & (4) & (5) & $(6)$ & (7) & (8) \\
\hline \multirow[t]{2}{*}{ CEO \% ownership } & -0.002 & & -0.003 & & -0.037 & & $-0.043 *$ & \\
\hline & $(0.002)$ & & $(0.002)$ & & $(0.026)$ & & $(0.025)$ & \\
\hline \multirow[t]{2}{*}{$\mathrm{CEO} \%$ equity risk } & 0.002 & & 0.002 & & $0.024 *$ & & 0.020 & \\
\hline & $(0.001)$ & & $(0.002)$ & & $(0.014)$ & & $(0.016)$ & \\
\hline \multirow[t]{2}{*}{ CEO \$ ownership } & & -0.003 & & $-0.005^{*}$ & & $-0.064 * *$ & & $-0.067 * *$ \\
\hline & & (0.003) & & $(0.003)$ & & $(0.027)$ & & $(0.029)$ \\
\hline \multirow[t]{2}{*}{ CEO $\$$ equity risk } & & 0.002 & & 0.002 & & $0.027 *$ & & 0.025 \\
\hline & & $(0.001)$ & & $(0.002)$ & & $(0.016)$ & & (0.018) \\
\hline \multirow[t]{2}{*}{ Lagged return } & -0.187 & -0.184 & -0.478 & -0.452 & $-0.593 * *$ & $-0.594 * *$ & -0.420 & -0.400 \\
\hline & $(0.232)$ & $(0.232)$ & $(0.495)$ & $(0.495)$ & $(0.240)$ & $(0.240)$ & $(0.434)$ & $(0.436)$ \\
\hline \multirow[t]{2}{*}{ Book-to-market } & $-0.059 * * *$ & $-0.060 * * *$ & $-0.074 * * *$ & $-0.075 * * *$ & $-0.827 * * *$ & $-0.838 * * *$ & $-0.879 * * *$ & $-0.883 * * *$ \\
\hline & $(0.020)$ & $(0.020)$ & $(0.021)$ & $(0.021)$ & $(0.225)$ & $(0.225)$ & $(0.226)$ & $(0.226)$ \\
\hline \multirow[t]{2}{*}{ Log (market value) } & -0.002 & -0.000 & 0.001 & 0.004 & -0.021 & 0.016 & 0.007 & $0.050 *$ \\
\hline & $(0.002)$ & $(0.002)$ & $(0.002)$ & $(0.003)$ & $(0.020)$ & $(0.024)$ & $(0.022)$ & $(0.026)$ \\
\hline \multirow[t]{2}{*}{ Tier 1 capital ratio } & & & 0.002 & 0.002 & & & 0.024 & 0.023 \\
\hline & & & $(0.002)$ & $(0.002)$ & & & $(0.017)$ & $(0.017)$ \\
\hline Observations & 85 & 85 & 74 & 74 & 84 & 84 & 74 & 74 \\
\hline R-squared & 0.14 & 0.14 & 0.24 & 0.24 & 0.23 & 0.23 & 0.31 & 0.31 \\
\hline
\end{tabular}




\section{Table 7: Dollar Loss of CEOs' equity portfolios during the credit crisis}

The table shows the cumulative trading losses and the losses from shares held from the beginning to the end of the sample period. The sample contains 80 bank CEOs. A CEO who turned over prior to September 2007 is excluded from the sample. Cumulative trading losses are calculated as shares sold multiplied with the difference of the price at the fiscal year end 2006 and the transaction price. Only insider sales unrelated to option exercises are included in the calculations. The 'loss from not acting' is calculated as the shares held at the end of the sample period multiplied with the difference of the fiscal year end price 2006 and the stock price at the end of the sample period. End of the sample period is defined as either December 2008, the month of the turnover of the CEO, or the month of the corporate event (merger, delisting), whichever comes earlier. The 'total loss' is calculated as the sum of the cumulative trading loss and the loss from not acting. If Thomson Financial does not report a sale of shares unrelated to options, it is assumed that the CEO did not sell any of his shares, and cumulative trading losses are set to zero. All numbers, except for stock prices, are reported in thousands of dollars.

\begin{tabular}{lrrrrrr} 
& \multicolumn{1}{c}{ Mean } & Maximum & \multicolumn{1}{c}{ Q3 } & Median & \multicolumn{1}{c}{ Q1 } & Minimum \\
\hline $\begin{array}{l}\text { Stock price end of fiscal } \\
\text { year 2006 }\end{array}$ & 40.36 & 11.12 & 23.95 & 35.58 & 48.75 & 152.48 \\
$\begin{array}{l}\text { Stock price end of sample } \\
\text { period }\end{array}$ & 21.91 & 0.10 & 7.98 & 14.72 & 32.38 & 89.65 \\
$\begin{array}{l}\text { Total value of shares held } \\
\text { end of fiscal year 2006 }\end{array}$ & 61503.82 & 347.48 & 7065.16 & 23628.25 & 57337.03 & 894128.54 \\
Loss from not acting & 28771.49 & 368429.27 & 19150.44 & 5076.10 & 784.05 & -13628.19 \\
Cumulative trading loss & 2719.45 & 201538.71 & 56.63 & 0.00 & 0.00 & -686.16 \\
Total dollar loss & 31490.94 & 368429.27 & 20315.48 & 5084.30 & 916.83 & -13628.19
\end{tabular}




\section{Figure 1: Cumulative weekly portfolio returns July 2007 - December 2008}

The figure shows cumulative weekly portfolio returns for a portfolio of high CEO ownership financial firms, for a portfolio of low CEO ownership banks, and for a longshort portfolio where the high CEO ownership banks are bought. Firms are classified as high ownership if the ownership of the CEO at the end of fiscal year 2006 is in the top quartile of all sample CEOs. Ownership is a dollar ownership measure, which is equal to the dollar change in the executive's portfolio for a $1 \%$ change in the stock price.

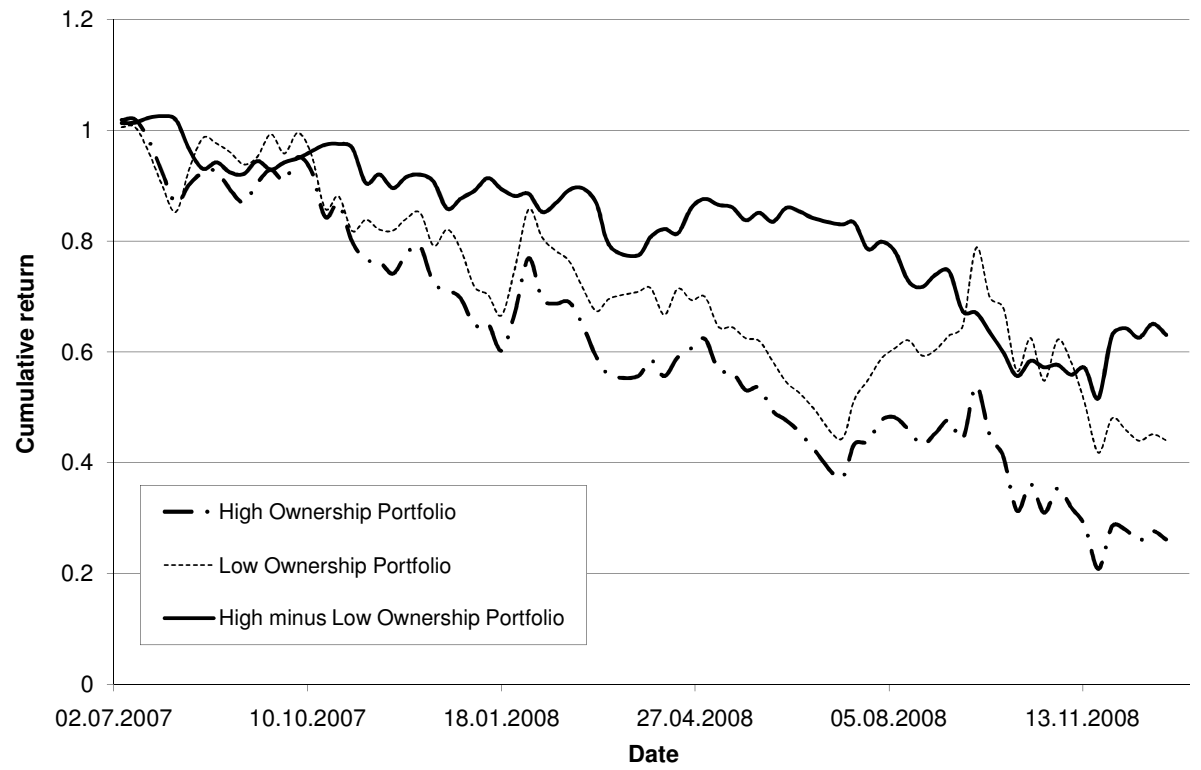


Figure 2: Evolution of net income over assets 2006Q1 - $2008 Q 3$

The figure plots the evolution of average and median net income / total assets of a sample of 100 bank holding companies and investment banks for 12 quarters from 2005Q4 to 2008 Q3.

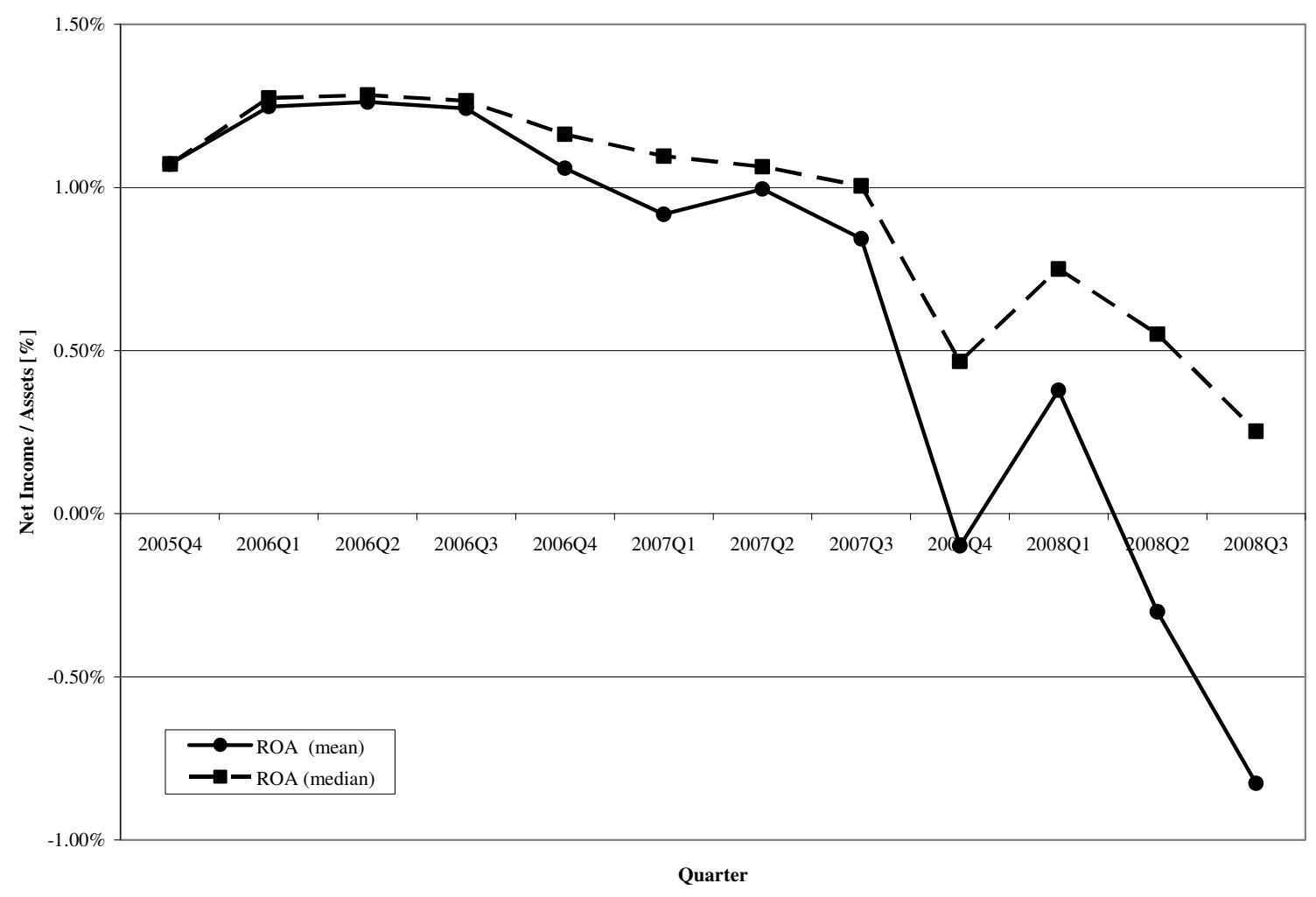




\section{Figure 3: CEO insider trading}

The figure shows the average total percentage changes in CEO ownership and ownership changes caused by trading and new grants. The sample contains 80 bank CEOs that are covered by both Execucomp and Thomson Financial's insider trading database. A CEO who turned over prior to September 2007 is excluded from the sample. For each CEO, all insider transactions reported by Thomson Financial are aggregated by firm and quarter. If a CEO does not trade or does not receive new grants, he is not included in the cross-sectional average for a given quarter. The percentage change in ownership is defined as the number of shares (or derivatives) traded divided by the total CEO ownership from stocks and options at the end of fiscal year 2006.

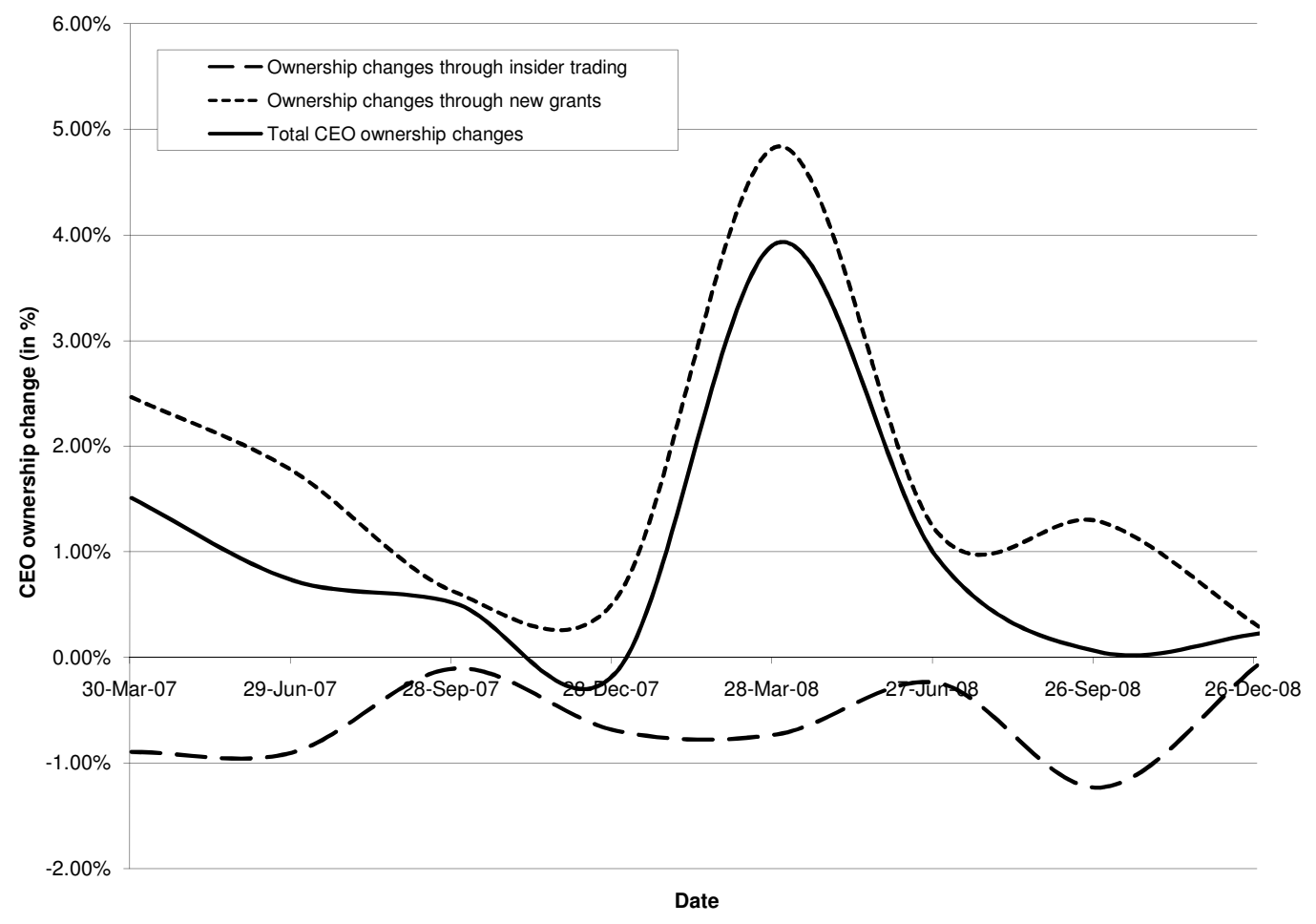

